\title{
Behavior's Green Consumer Model Development (Green Consumer Study in North Sulawesi, Indonesia)
}

\author{
Allen A. Ch. Manongko, Henry J. D. Tamboto \\ Faculty of Economics, Manado State University-Indonesia
}

\begin{abstract}
The purpose of this study is to analyze and explain the relationships and effects of green marketing, theory of planned behavior on green consumerism and environmental sustainability through green consumer behavior. The research design uses a quantitative approach through survey methods. The population in this study are consumers who buy and are willing to conduct interviews about green products in modern markets and souvenirs in a number of districts / cities in North Sulawesi province. The research sample analyzed was 381 respondents. Sampling using a purposive sampling technique with data analysis techniques using structural equation models with the help of AMOS, SPSS, and Ms Exel programs. A number of variables in this study are green marketing, theory of planned behavior, green consumer behavior, green consumerism and environmental sustainability. The research findings produce: 1) Equation 1 formed $\mathrm{Y} 1=0.408 \mathrm{X} 1+0.195 \mathrm{X} 2$, meaning that green marketing and the theory of planned behavior have a positive relationship and have a significant effect on green consumer behavior; 2) Persuasion 2 is formed $\mathrm{Y} 2=0.137 \mathrm{X} 1+0.130 \mathrm{X} 2+0.489 \mathrm{Y} 1$, meaning green marketing and theory of planned behavior have a positive relationship and have a significant effect on green consumerism through green consumer behavior; 3) Perservation 3 is formed Y3 $=0.122 \mathrm{X} 1+0.021 \mathrm{X} 2+0.570 \mathrm{Y} 1$, meaning that green marketing and theory of planned behavior have a positive relationship and have a significant effect on environmental sustainability through green consumer behavior. With the findings of this study, it can be concluded that the green consumer behavior model is a model that can be considered in developing green product development strategies.
\end{abstract}

Keywords: Green Marketing, Theory of Planned Behaviour, Green consumer behavior, Green consumerism, Environmental sustainability

DOI: $10.7176 / \mathrm{EJBM} / 11-27-15$

Publication date:September $30^{\text {th }} 2019$

\section{Introduction}

In recent years the level of awareness of the world community on the importance of a sustainable, healthy and green environment tends to increase. Awareness and concern for "healthy and green" currently engulfing global consumers and has become a community movement that has a real influence. A global awareness that environmental and health issues are common issues and can only be overcome if each individual actively and collectively mobilizes to contribute.

Today, many consumers have realized that their consumption patterns can have a direct impact on many environmental problems. So they apply this awareness to their consumption patterns by considering environmental issues in shopping, such as paying attention to whether the packaging of a product can be recycled or not (Laroche et al., 2001). This situation is a challenge for marketers to be able to meet the increasing demand by remaining socially responsible and environmentally responsible, ie maintaining environmental sustainability (Istantia et al. 2016; Nair \& Maram, 2015). Some producers also change their production strategies by using raw materials that are safe for the environment and cause a new phenomenon in the world of marketing called green marketing or environmentally friendly marketing (Agustin et al. 2015). Green marketing refers to holistic marketing where marketing activities utilize limited resources (Anika, 2014), applied by the company and will provide encouragement to consumers who are selective in purchasing products so that the products produced by companies that implement these concepts will be more sought after and liked by consumers .

In Indonesia, environmental awareness is increasing, it can be seen from the growth of movements such as earth day, going to work using a bicycle, also the existence of a vehicle free day and several movements that support environmental preservation activities and healthier lifestyle movements. With the support of an increasingly improved environment for education and increased purchasing power. Indonesia can become a potential market for marketers who want to apply the concept of green marketing, as some other Asian countries have potential, information about green consumer behavior (green consumer behavior), although still relatively little compared to in developed countries that have already started the caring movement environment (Lee, 2014). The sustainability of green consumer behavior is very possible to become a global consumerism movement that presents green consumerism as a lifestyle that is concerned about environmental sustainability.

The purpose of this study is to analyze and explain the relationships and effects of green marketing and the theory of planned behavior on green consumerism and environmental sustainability through green consumer behavior as mediation. 


\section{Literature Review}

\subsection{Green Consumer Behavior}

According to Engel \& Blackwell (1982), "a consumer behavior is an action that is directly involved to get things, consumptions, and to use those things (products or services), including the decision process before and follow that decision." According to Sumarwan (2011), consumer behavior is all activities, actions, and psychological processes that encourage such actions before buying, when buying, using, spending products and services after doing the above or evaluating activitiesStudies related to green consumer behavior focus on behaviors that can reduce resources and energy use (Gardner \& Stern, 2002).

According to Siringi (2012) Green consumer is an individual whose behavior is influenced by his concern for the environment, which is reflected in how the individual searches for, buys, uses, evaluates, and disposes of the product. This behavior is called "green consumer behavior". The behavior of consumers who care about the environment will affect their desire to consume environmentally friendly products (Andrew \& Slamet, 2013).

\subsection{Green Marketing}

The American Marketing Association (AMA) defines that "green marketing is the marketing of products that are presumed to be environmentally safe. This green marketing incorporates a broad range of activities, including product modification, changes to the productions process, packaging, changes, as well as modifying advertising "(Istantia, et al. 2016). That is, green marketing is marketing that markets products that are considered safe for the environment. This includes several things such as product modification, changes in the production process, packaging, to changes in the promotion process.

Mintu and Lozada define green marketing as the application of marketing tools to provide change facilities for organizational satisfaction and individual goals in carrying out maintenance, protection, and conservation activities for natural resources (Silvia, H, \& Kusumawati, 2014). Green marketing objectives according to Grant, divided into three stages: Green stage; Greener stage; The greenest stage (Silvia, H, \& Kusumawati, 2014).

The marketing mix in green marketing is a marketing mix that must be responsive to environmental problems because it aims at environmental sustainability which consists of: Green Product; Green Price; Green Place; and Green Promotion (Agustin, et al. 2015; Silvia, H, \& Kusumawati, 2014)Some green marketing strategies that can be adapted, namely: 1. Successful market segmentation and concentration on selected market segmentation; 2. Developing a new generation of green product; 3. Green Positioning; 4. Applying Green Promotion; 5. Green Packaging; 6. Deciding about Green Prices; 7. Applying "green" logistics; 8. Changing the attitude towards waste (Nandini, 2016).

\subsection{Environmental Sustainability}

Morelli (2011) defines "environmental sustainability could be defined as a condition of balance, resilience, and interconnectedness that allows human society to satisfy its needs while not exceeding the capacity of its supporting ecosystems to continue to regenerate the services necessary to meet those needs nor by our actions diminishing biological diversity ". That is, environmental sustainability is a condition of balance, resilience, and interconnectedness that gives people the freedom to meet their needs without exceeding the capacity of supporting ecosystems to continue to meet their needs without destroying biodiversity. The process of meeting human needs is inseparable from buying or buying activities. And producers who are aware of sustainability, trying to meet the needs of individuals (consumers) for a long time. This means designing and marketing products that can be used universally by consumers around the world without endangering both consumers and the environment (sustainable marketing).

\subsection{Green Consumerism}

Defined as "the use of individual consumer preferences to promote less environmentally damaging products and services" (Smith, 1998). Green consumerism arises from the awareness and formation of individual consumer preferences for the products they want to consume. Furthermore, the desired product is not truly "green", but rather a slightly reduced level of damage that can be caused. This shows the understanding that creating products that are one hundred percent safe for the environment is very difficult to achieve. There are too many trade offs, both on price, durability, product performance, comfort, and other criteria.Green consumers have the belief that: 1) there are real environmental problems, 2) these problems must be dealt with seriously and addressed in an active way, 3) they feel they have sufficient information in their daily lives, 4) every individual can and must provide contribution in saving the earth from frightening environmental disasters (Smith, 1998).

\subsection{Theory of Planned Behavior}

Theory of planned behavior (TPB) is a further development of the theory of reasoned action (TRA) by Ajzen. Ajzen added a construct that did not yet exist in TRA. This construct is called perceived behavioral control. This construct was added to the TPB to control individual behavior that was limited by its shortcomings and 
limitations from the lack of resources used to conduct its behavior (Ajzen, I. 1988).Ajzen (1991) suggests a theory of planned behavior (theory of planned behavior), namely: Attitudes towards behavior and its influence on interests and behavior. Attitude (attitude) is an evaluation of the belief (belief) or positive or negative feelings from someone if they have to do the specified behavior; Subjective norms and their influence on interests and behavior. Ajzen argues that subjective norms are one's perceptions or views of other people's beliefs that will affect the interest in doing or not performing the behavior under consideration; and Control of perceived behavior and its influence on behavioral interest. Perceived behavior control is defined by Ajzen as the perceived ease or difficulty of performing "the perceived ease or difficult of performing the behavior". Perceived behavioral control is defined as perceptions and internal and external constructs of behavior. This perceived behavioral control controls reflect past experiences and also anticipate existing obstacles.

\subsection{Green Products}

Kasali (2005) provides a definition of green products (green products) as an illustration of goods or products produced by producers that are related to a sense of security and do not have an impact on human health and do not have the potential to damage the environment. In addition, clean products are also associated with the use of raw materials that always pay attention to future generations, clean products also aim to reduce waste (waste) both from the process and from the product's life cycle. Furthermore, Nugrahadi (2002) states that clean products (green products) are always environmentally oriented. According to Ottman (1998) states that green products in principle can last for a long period of time, do not contain toxins, are made from materials that are environmentally friendly and can be recycled, or packaged in a simple (simple) and minimalist manner. Green products are made, disseminated, and used to reduce negative impacts on the environment such as damage and pollution to the environment.

\section{Method Research}

The research design uses a quantitative approach through survey methods. The population in this study are consumers who buy and are willing to conduct interviews about green products in modern markets and souvenirs in a number of districts / cities in North Sulawesi Province. The research sample analyzed was 381 respondents. Sampling using a purposive sampling technique with data analysis techniques using structural equation models with the help of AMOS, SPSS, and Ms Exel programs. The variables in this study are 1) Green marketing, with indicators: succesful market segmentation and concentration on selected market segmentation; developing a new generation of green product; green positioning; applying green promotion; green packaging; deciding about green prices; applying green logistics; changing the attitude towards waste; 2) Theory of planned behavior, with indicators: attitude; subjective norms; perceived behavioral control; 3) Green consumer behavior, with indicators: economic factors; psychological; factors; situational / demographic factor; environmental factors; 4) Green consumerism, with indicators: gifts; attractive packaging; maintain self-appearance and style; price considerations; maintain status symbols; conformity element model; gives confidence; 5) Environmental sustainability, with indicators: environmental systems; reducing environmental stresses; reducing human vulnerability; social and institutional capacity; global stewardship. 


\section{Result and Discussion}

4.1.Result

Descriptive Respondents.

Table 1. Descriptive Respondents by Region

\begin{tabular}{|r|l|r|r|}
\hline No & \multicolumn{1}{|c|}{ District / City } & Number of sample & Prosentase \\
\hline 1 & Kota Manado & 105 & 28 \\
\hline 2 & Kota Tomohon & 58 & 15 \\
\hline 3 & Kota Bitung & 26 & 7 \\
\hline 4 & Kota Kotamobagu & 21 & 6 \\
\hline 5 & Kab. Minahasa & 74 & 19 \\
\hline 6 & Kab. Minahasa Selatan & 17 & 4 \\
\hline 7 & Kab. Minahasa Utara & 22 & 6 \\
\hline 8 & Kab. Minahasa Tenggara & 8 & 2 \\
\hline 9 & Kab. Sitaro & 6 & 2 \\
\hline 10 & Kab. Sangihe & 12 & 3 \\
\hline 11 & Kab. Talaud & 0 & 0 \\
\hline 12 & Kab. Bolmong & 18 & 5 \\
\hline 13 & Kab. Bolmong Selatan & 0 & 0 \\
\hline 14 & Kab. Bolmong Timur & 0 & 4 \\
\hline 15 & Kab. Bolmong Utara & 381 & 0 \\
\hline & Total & 100 \\
\hline
\end{tabular}

Based on the table and figure above, respondents in this study show that the city of Manado is the region with the highest number of respondents, followed by the Minahasa regency and the city of Tomohon.

Validity Testji Validitas

Table 2. Recapitulation of Validity Test Results

\begin{tabular}{|c|c|c|c|c|c|c|}
\hline \multirow{2}{*}{ Variable } & \multirow{2}{*}{$\begin{array}{c}\text { Number of } \\
\text { indicator }\end{array}$} & \multirow{2}{*}{$\begin{array}{l}\text { Number } \\
\text { of Item }\end{array}$} & \multicolumn{2}{|c|}{$\begin{array}{c}\text { Pearson } \\
\text { correlation value } \\
\end{array}$} & \multirow{2}{*}{$\begin{array}{l}\text { Cut } \\
\text { Off }\end{array}$} & \multirow{2}{*}{ Information } \\
\hline & & & $\begin{array}{c}\text { The } \\
\text { smallest }\end{array}$ & $\begin{array}{c}\text { The } \\
\text { biggest }\end{array}$ & & \\
\hline Green Marketing $\left(\mathrm{X}_{1}\right)$ & 8 & 16 & 0.574 & 0.763 & 0.3 & Valid \\
\hline Theory of Planned Behavior $\left(\mathrm{X}_{2}\right)$ & 3 & 6 & 0.691 & 0.782 & 0.3 & Valid \\
\hline Green Consumer Behavior $\left(\mathrm{Y}_{1}\right)$ & 4 & 8 & 0.497 & 0.723 & 0.3 & Valid \\
\hline Green Consumerism $\left(\mathrm{Y}_{2}\right)$ & 7 & 14 & 0.546 & 0.778 & 0.3 & Valid \\
\hline Environmental Sustaniability $\left(\mathrm{Y}_{2}\right)$ & 5 & 10 & 0.338 & 0.507 & 0.3 & Valid \\
\hline
\end{tabular}

Based on the results of the validity test recapitulation, showing that all items have a Pearson correlation coefficient value $>$ critical value (0.3), it means that all items of the 5 variables are valid.

Table 3. Recapitulation of Reliability Test Results

\begin{tabular}{|l|c|c|c|c|c|}
\hline \multirow{2}{*}{\multicolumn{1}{|c|}{ Variabel }} & \multirow{2}{*}{$\begin{array}{c}\text { Number } \\
\text { of }\end{array}$} & \multicolumn{2}{|c|}{$\begin{array}{c}\text { Alpha Cronbach } \\
\text { Value }\end{array}$} & \multirow{2}{*}{ Cut Off } & \multirow{2}{*}{ Information } \\
& indicator & $\begin{array}{c}\text { The } \\
\text { smallest }\end{array}$ & $\begin{array}{c}\text { The } \\
\text { biggest }\end{array}$ & & \\
\hline Green Marketing $\left(\mathrm{X}_{1}\right)$ & 8 & 0.762 & 0.897 & 0.6 & Reliabel \\
\hline Theory of Planned Behavior $\left(\mathrm{X}_{2}\right)$ & 3 & 0.725 & 0.769 & 0.6 & Reliabel \\
\hline Green Consumer Behavior $\left(\mathrm{Y}_{1}\right)$ & 4 & 0.745 & 0.772 & 0.6 & Reliabel \\
\hline Green Consumerism $\left(\mathrm{Y}_{2}\right)$ & 7 & 0.694 & 0.884 & 0.6 & Reliabel \\
\hline Environmental Sustaniability $\left(\mathrm{Y}_{2}\right)$ & 5 & 0.745 & 0.840 & 0.6 & Reliabel \\
\hline
\end{tabular}

Based on the results of the reliability test recapitulation, showing that all indicators have a coefficient value of alpha cronbach $>$ critical value (0.6), it means that all 5 variables are reliable. 
Table 4. Linearity Test Results

\begin{tabular}{lrlll}
\hline & Relationship & F & Prob. \\
\hline Green Marketing & $\rightarrow$ & Green Consumer Behavior & 53.811 & 0.000 \\
Theory of Planned Behavior & $\rightarrow$ & Green Consumer Behavior & 31.323 & 0.000 \\
Green Marketing & $\rightarrow$ & Green Consumerism & 51.622 & 0.000 \\
Theory of Planned Behavior & $\rightarrow$ & Green Consumerism & 30.513 & 0.000 \\
Green Marketing & $\rightarrow$ & Environmental Sustaniability & 33.151 & 0.000 \\
Theory of Planned Behavior & $\rightarrow$ & Environmental Sustaniability & 27.839 & 0.000 \\
Green Consumer Behavior & $\rightarrow$ & Green Consumerism & 62.674 & 0.000 \\
Green Consumer Behavior & $\rightarrow$ & Environmental Sustaniability & 65.991 & 0.000 \\
\hline
\end{tabular}

Based on the table above it is known that all relationships between exogenous variables and endogenous variables produce a probability of 0.000 . This means that the probability $<$ level of significance (alpha $(\alpha=5 \%)$. Thus it can be stated that all relationships between exogenous variables and endogenous variables are linear relationships.

Outlier Assumption Test.

Outlier assumption testing is used to determine the existence of extreme values in the data used in this study. Outlier testing is done through mahalanobis distance criteria. Mahalanobis distance was evaluated using $\chi 2$ in the degree of freedom equal to the number of variables used in this study. Test criteria if there is a mahobobic distance greater than the critical value $\chi 2(\alpha, \mathrm{df})($ table) with an error rate of $5 \%$ alpha $(\chi 2$ table $=2258.88)$ then outliers can be identified. The test results show the minimum value of mahalanobis distance is 80,178 and the maximum value of mahalanobis distance is 131,920 . The results of the analysis show the maximum value of the mahalanobis distance is smaller than the critical value. Thus the data used in this study did not contain outliers.

\section{Structural Equation Model}

The feasibility test of the model construct is intended to find out whether the construct that is formed is appropriate (feasible) or not. There are several test indices in SEM analysis, namely the probabilities of the chi square test, RMSEA, GFI, AGFI, TLI and CFI. Criteria for testing using chi square states that if the probability value of the chi-square $\geq$ level of significant (alpha) then the construct formed is appropriate (feasible). The criteria for using RMSEA states that if the value of RMSEA cut cut-off value is $(0.08)$ then the construct formed is appropriate. And the Criteria using GFI, AGFI, TLI, and CFI state that if the goodness of fit value $\geq$ the cutoff value is $(0.90)$ then the construct formed is appropriate (feasible). The results of the construct feasibility test have been summarized as follows:

Table 5. Goodness of Fit

\begin{tabular}{cccc}
\hline Indeks & Goodness of Fit & Cut Off Value & Information \\
\hline Chi - Square & 28.566 & Kecil & Good Fit \\
RMSEA & $(1.000)$ & $\geq 0.05$ & \\
GFI & 0.000 & $\leq 0.08$ & Good Fit \\
AGFI & 0.986 & $\geq 0.90$ & Good Fit \\
TLI & 0.942 & $\geq 0.90$ & Good Fit \\
CFI & 1.018 & $\geq 0.95$ & Good Fit \\
\hline
\end{tabular}

Based on the summary of goodness of fit, it can be seen that the six indexes, namely chi-square, RMSEA, GFI, AGFI, TLI and CFI have criteria that match the cut-off value, so that the six indexes have been met. Thus the construct formed is stated as appropriate.

\section{Direct Effect Hypothesis Testing.}

Direct effect hypothesis testing is intended to test whether there is a direct influence of exogenous variables on endogenous variables. Significance testing can be determined through probability values. The testing criteria are done through: 1) Looking at the probability value, if the probability value is smaller $(<)$ than the level of significance (alpha $\alpha=5 \%$ ), then it is stated that there is a significant influence of exogenous variables on endogenous variables, and vice versa if the probability value is greater $(>)$ from the level of significance (alpha $\alpha=5 \%$ ), it is stated that there is no significant influence of exogenous variables on endogenous variables. 2). Looking at the C.R Index value, if the C.R index value is $\geq 2.0$, then the hypothesis is accepted, conversely, if the C.R index value is $\leq 2.0$, then the hypothesis is rejected. The results of the analysis are summarized below: 
Table 6. Direct Effect Hypothesis Testing Results

\begin{tabular}{|c|c|c|c|c|c|c|c|}
\hline \multicolumn{3}{|c|}{ Pengujian } & Koef & SE & C.R. & Prob & Information \\
\hline Green Marketing $\left(\mathrm{X}_{1}\right)$ & $\rightarrow$ & $\begin{array}{l}\text { Green Consumer Behavior } \\
\left(\mathrm{Y}_{1}\right)\end{array}$ & 0.408 & 0.031 & 6.061 & $0.000^{\mathrm{s}}$ & accepted \\
\hline $\begin{array}{l}\text { Theory of Planned Behavior } \\
\left(\mathrm{X}_{2}\right)\end{array}$ & $\rightarrow$ & $\begin{array}{l}\text { Green Consumer Behavior } \\
\left(\mathrm{Y}_{1}\right)\end{array}$ & 0.195 & 0.029 & 3.099 & $0.002^{\mathrm{s}}$ & accepted \\
\hline Green Marketing $\left(\mathrm{X}_{1}\right)$ & $\rightarrow$ & Green Consumerism $\left(\mathrm{Y}_{2}\right)$ & 0.137 & 0.035 & 2.264 & $0.024^{\mathrm{s}}$ & accepted \\
\hline $\begin{array}{l}\text { Theory of Planned Behavior } \\
\left(\mathrm{X}_{2}\right)\end{array}$ & $\rightarrow$ & Green Consumerism $\left(\mathrm{Y}_{2}\right)$ & 0.130 & 0.032 & 2.323 & $0.020^{\mathrm{s}}$ & accepted \\
\hline Green Marketing $\left(\mathrm{X}_{1}\right)$ & $\rightarrow$ & $\begin{array}{l}\text { Enviromental Sustaniability } \\
\left(\mathrm{Y}_{3}\right)\end{array}$ & 0.122 & 0.034 & 0.358 & $0.721^{\mathrm{ns}}$ & reject \\
\hline $\begin{array}{l}\text { Theory of Planned Behavior } \\
\left(\mathrm{X}_{2}\right)\end{array}$ & $\rightarrow$ & $\begin{array}{l}\text { Enviromental Sustaniability } \\
\left(\mathrm{Y}_{3}\right)\end{array}$ & 0.021 & 0.032 & 2.271 & $0.023^{\mathrm{s}}$ & accepted \\
\hline $\begin{array}{l}\text { Green Consumer Behavior } \\
\left(\mathrm{Y}_{1}\right)\end{array}$ & $\rightarrow$ & Green Consumerism $\left(\mathrm{Y}_{2}\right)$ & 0.489 & 0.1 & 6.075 & $0.000^{\mathrm{s}}$ & accepted \\
\hline $\begin{array}{l}\text { Green Consumer Behavior } \\
\left(\mathrm{Y}_{1}\right)\end{array}$ & & $\begin{array}{l}\text { Enviromental Sustaniability } \\
\left(\mathrm{Y}_{3}\right)\end{array}$ & 0.570 & 0.104 & 6.985 & $0.000^{\mathrm{s}}$ & accepted \\
\hline
\end{tabular}

Indirect Effect Hypothesis Testing (Indirect Effect)

The indirect effect testing is intended to test whether there is an influence of exogenous variables indirectly on endogenous variables through mediating / intervening variables. The indirect effect testing in this study was carried out with the sobel test. This sobel test is carried out to test the mediating or interviening variables in a model.The testing criteria are carried out through: 1) Looking at the probability value, if the probability value is smaller $(<)$ than the level of significance (alpha $\alpha=5 \%$ ) then it is stated that there is a significant influence of exogenous variables on endogenous variables through mediating / intervening variables, and vice versa if the value the probability is greater $(>$ ) than the level of significance (alpha $\alpha=5 \%$ ), so there is no significant influence of exogenous variables on endogenous variables through mediating / intervening variables. 2). Looking at the C.R Index value, if the C.R index value is $\geq 2.0$, then the hypothesis is accepted, conversely, if the C.R index value is $\leq 2.0$, then the hypothesis is rejected.The results of the analysis are summarized below:

Table 7 Indirect Effect Hypothesis Testing Results

\begin{tabular}{|c|c|c|c|c|c|c|c|}
\hline Eksogen & Mediasi & Endogen & Koef $^{(\mathrm{M})}$ & $\mathrm{SE}^{(\mathrm{S})}$ & C.R $\mathrm{R}^{(\mathrm{S})}$ & Prob & Information \\
\hline $\begin{array}{ll}\begin{array}{l}\text { Green } \\
\left(\mathrm{X}_{1}\right)\end{array} & \text { Marketing } \\
\end{array}$ & $\begin{array}{l}\text { Green Consumer } \\
\text { Behavior }\left(\mathrm{Y}_{1}\right)\end{array}$ & $\begin{array}{l}\text { Green } \\
\text { Consumerism }\left(\mathrm{Y}_{2}\right)\end{array}$ & 0.199 & 0.044 & 4.572 & 0.000 & accepted \\
\hline $\begin{array}{l}\text { Green } \\
\left(X_{1}\right)\end{array}$ & $\begin{array}{l}\text { Green Consumer } \\
\text { Behavior }\left(\mathrm{Y}_{1}\right)\end{array}$ & $\begin{array}{l}\text { Enviromental } \\
\text { Sustaniability }\left(\mathrm{Y}_{3}\right)\end{array}$ & 0.233 & 0.046 & 5.047 & 0.000 & accepted \\
\hline $\begin{array}{l}\text { Theory of Planned } \\
\text { Behavior }\left(\mathrm{X}_{2}\right)\end{array}$ & $\begin{array}{l}\text { Green Consumer } \\
\text { Behavior }\left(\mathrm{Y}_{1}\right)\end{array}$ & $\begin{array}{l}\text { Green } \\
\text { Consumerism }\left(\mathrm{Y}_{2}\right)\end{array}$ & 0.095 & 0.024 & 3.926 & 0.000 & accepted \\
\hline $\begin{array}{l}\text { Theory of Planned } \\
\text { Behavior }\left(\mathrm{X}_{2}\right)\end{array}$ & $\begin{array}{l}\text { Green Consumer } \\
\text { Behavior }\left(\mathrm{Y}_{1}\right)\end{array}$ & $\begin{array}{l}\text { Enviromental } \\
\text { Sustaniability }\left(\mathrm{Y}_{3}\right)\end{array}$ & 0.111 & 0.026 & 4.220 & 0.000 & accepted \\
\hline
\end{tabular}

Path Diagram into Structural Model

The conversion of the path diagram into the measurement model is intended to determine the strength of the influence between constructs described in the effect on the model, namely the direct effect and the indirect effect, as shown in the figure below: 


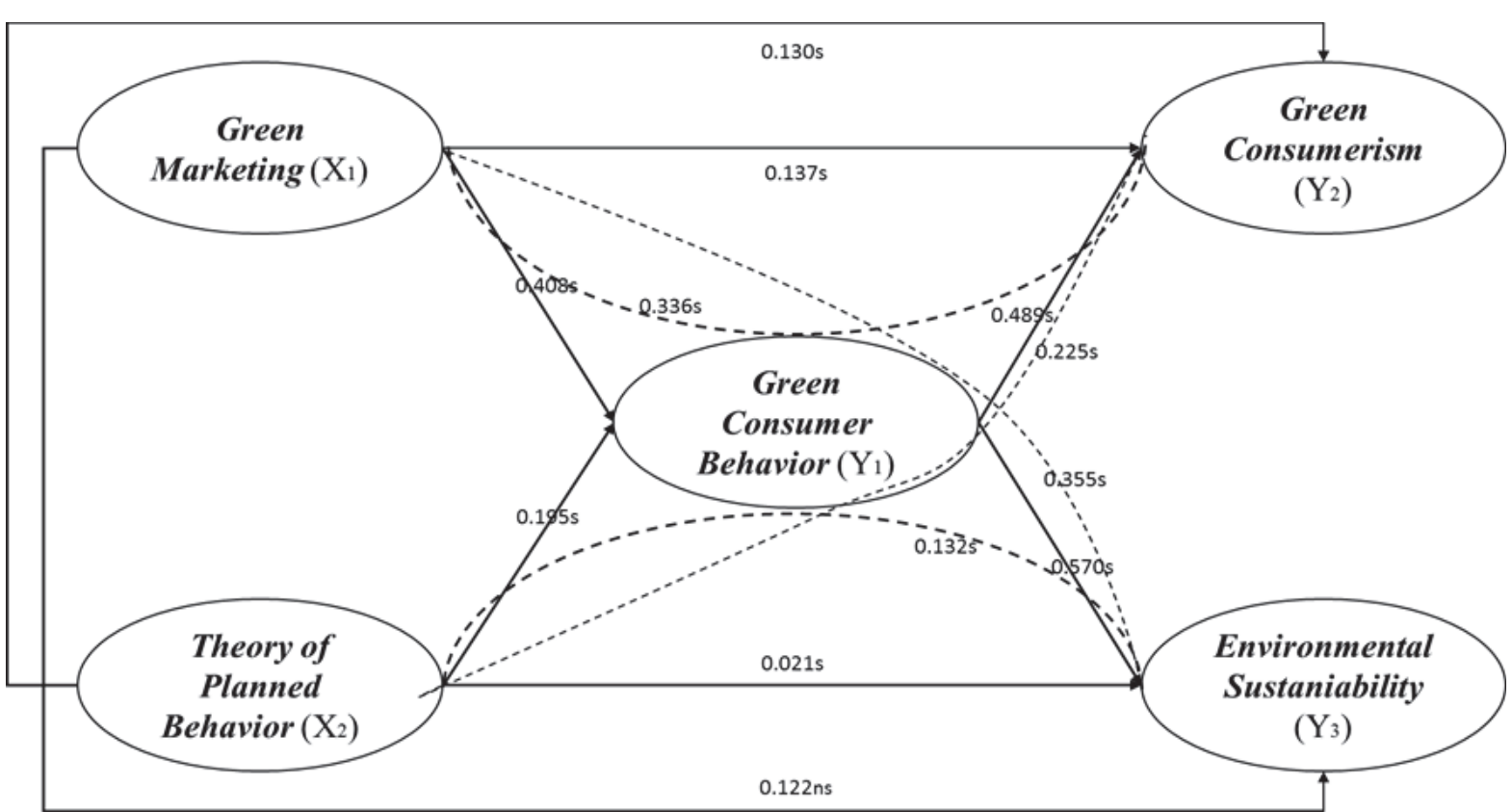

The formulas that are formed are:

Equation 1: $\mathrm{Y} 1=0.408 \mathrm{X} 1+0.195 \mathrm{X} 2$

From equation 1 it can be explained that: The direct effect coefficient of green marketing (X1) and theory of planned behavior (X2) on green consumer behavior (Y1) of 0.408 and 0.195 states that green marketing (X1) and theory of planned behavior (X2) influence positive and significant impact on green consumer behavior (Y1). This means that the higher the green marketing coefficient (X1) and the theory of planned behavior (X2), the green consumer behavior $(\mathrm{Y} 1)$ will also increase.

Equation 2: $\mathrm{Y} 2=0.137 \mathrm{X} 1+0.130 \mathrm{X} 2+0.489$ Y1From equation 2 it can be explained that: The indirect effect coefficient of green marketing (X1) on green consumerism (Y2) through green consumer behavior (Y1) of 0.137 states that green marketing (X1) has a positive and significant effect on green consumerism (Y2) through green consumers behavior (Y1). That is, if the green consumer behavior (Y1) coefficient value is higher, the higher the green marketing (X1) increases green consumerism (Y2).The indirect effect coefficient theory of planned behavior (X2) on green consumerism (Y2) through green consumer behavior (Y1) of 0.130 states that the theory of planned behavior (X2) has a positive and significant effect on green consumerism (Y2) through green consumer behavior (Y1) ). That is, if the green consumer behavior (Y1) coefficient value is higher, the higher the green marketing (X1) increases green consumerism (Y2)

Equation 3: $\mathrm{Y} 3=0.122 \mathrm{X} 1+0.021 \mathrm{X} 2+0.570$ Y1From equation 3 it can be explained that: The indirect effect coefficient of green marketing (X1) on environmental sustainability (Y3) through green consumer behavior (Y1) of 0.233 states that green marketing (X1) has a positive and significant effect on environmental sustainability (Y3) through green consumers behavior (Y1). That is, if the green consumer behavior (Y1) coefficient value is higher, the higher the green marketing (X1) will increase environmental sustainability (Y3).

The indirect effect coefficient theory of planned behavior (X2) on environmental sustainability (Y3) through green consumer behavior (Y1) of 0.111 states that the theory of planned behavior (X2) has a positive and significant effect on environmental sustainability (Y3) through green consumer behavior (Y1) ). That is, if the green consumer behavior ( $\mathrm{Y} 1)$ coefficient value is higher, the higher the theory of planned behavior (X2) increases environmental sustainability (Y3).

\section{Effect of Dominant Variables}

Based on tables 4 and 5 , the effects of the model above can be seen that the parameter values of the exogenous variables that have been estimated have the highest grand total effects, so it can be stated that the exogenous variables have the strongest or dominant influence on their endogenous variables.

1) The dominant influence on green consumer behaviorThe variable that has the greatest total effect on green consumer behavior is green marketing with a grand total effect of 0.408 . This means that green marketing has a dominant influence on green consumer behavior.

2) The dominant influence on green consumerismThe variable that has the greatest total effect on green consumerism is green consumer behavior with a total effect of 0.489 . This means that green consumer behavior has a dominant influence on green consumerism.

3) Dominant influence on environmental sustainabilityThe variable that has the greatest total effect on 
environmental sustainability is green consumer behavior with a total effect of 0.570 . This means that green consumer behavior has a dominant influence on environmental sustainability.

\subsection{Discussion}

The influence of green marketing on green consumerism through green consumer behavior Community Empowerment affects directly to the Organizational Commitment

Based on the research findings revealed that green consumer behavior has a strategic role mediating a positive relationship and the significant influence of green marketing on green consumerism. This is in line with the opinions of Siringi (2012) and Andrew \& Slamet (2013), and Smith (1998) who explain that individuals who have a concern for the environment will consciously and formed as a preference for green or environmentally friendly products. By Nandini (2016), Istantia, et al. (2016), and Nair \& Maram (2015) guarantee that a green marketing strategy is very appropriate to be applied in explaining green consumer behavior that makes individuals or consumers bound as green consumerism.

The influence of theory of planned behavior on green consumerism through green consumer behavior

Based on the research findings revealed that green consumer behavior has a strategic role mediating a positive relationship and the significant influence of theory of planned behavior on green consumerism. That is, green consumer behavior is a determining factor in revealing the existence of theory of planned behavior towards green consumerism. This is consistent with the findings and statements of Ajzen (1991) which illustrate that attitudes, subjective norms and behavior control have the ability to explain individuals or green consumers in behavior. In line with the phrase Siringi (2012), Andrew \& Slamet (2013), and Smith (1998) that the formation of awareness and awareness of environmentally friendly products is the initial preference of green consumer behavior as green consumerism. By Lee (2014) said the sustainability of green consumer behavior is very possible to become a global consumerism movement that presents green consumerism as a lifestyle.

The influence of green marketing on environmental sustainability through green consumer behavior.

Based on the research findings revealed that green consumer behavior is a very strong factor mediating a positive relationship and the significant influence of green marketing on environmental sustainability. This is caused by the research findings describing the insignificance of the direct influence of green marketing on environmental sustainability. That is, the ability of green marketing indicators to explain environmental sustainability is less able, so the involvement of green consumer behavior mediates these two factors to reflect a real relationship and influence. This justifies the opinion of Siringi (2012) and Andrew \& Slamet (2013), and Smith (1998), that green marketing indicators are not always able to parse the existence of environmental sustainability, this is strong enough to explain that environmental stewardship and awareness of life healthy is naturally formed, which then becomes a preference for individuals or consumers to behave green. According to Istantia, et al. (2016), and Nair \& Maram (2015) point out that the challenge for marketers is socially and environmentally responsible, while maintaining environmental sustainability.

The influence of theory of planned behavior on environmental sustainability through green consumer behavior Based on research findings prove that green consumer behavior is an intermediate variable that can increase positive relationships and the significant influence of theory of planned behavior on environmental sustainability. That is, green consumer behavior has the ability to explain the indicators of the theory of planned behavior towards environmental sustainability. This is revealed by Lee's opinion (2014) which explains that several other Asian countries have potential, information about green consumer behavior (green consumer behavior), although it is still relatively small compared to developed countries that have already started the environmental care movement. So that the sustainability of green consumer behavior is very possible to become a global consumerism movement that presents green consumerism as a lifestyle that is concerned about environmental sustainability. For this reason Ajzen (1991) revealed that attitudes, subjective norms and behavior control have the ability to explain the interests and behavior of individuals or consumers in making decisions to buy. Likewise, Siringi (2012), Andrew \& Slamet (2013), and Smith (1998) that the formation of awareness and awareness of environmentally friendly products is a consideration for green consumers to behave.

\section{Effect of green consumer behavior on green consumerism}

Based on research results prove that green consumer behavior has a positive relationship and a significant influence on green consumerism. This explains that economic factors, psychological; factors, situational / demographic factors, environmental factors, as indicators of green consumer behavior can reveal the existence of green consumerism with gifts, attractive packaging, maintain self-appearance and style, price considerations, maintain status symbols, model conformity element, and gives confidence, as an indicator. Lee (2014) explains that the sustainability of green consumer behavior is very possible to become a global consumerism movement 
that presents green consumerism as a lifestyle. Smith (1998) adds that green consumerism arises from the awareness and formation of individual consumer preferences for the products they want to consume. Likewise Andrew \& Slamet (2013) said the behavior of consumers who care about the environment will affect their desire to consume environmentally friendly products.

The effect of green consumer behavior on environmental sustainability

Based on the research findings agreed that green consumer behavior has a positive relationship and a significant influence on environmental sustainability. This means that economic factors, psychological; factors, situational / demographic factors, environmental factors, as indicators of green consumer behavior have a strategic role to reveal the existence of environmental sustainability variables with environmental systems, reducing environmental stresses, reducing human vulnerability, social and institutional capacity, global stewardship, as an indicator. That is, green consumer behavior has the ability to explain indicators of environmental sustainability. This is revealed by Lee's opinion (2014) which explains that several other Asian countries have potential, information about green consumer behavior (green consumer behavior), although it is still relatively small compared to developed countries that have already started the environmental care movement. The sustainability of green consumer behavior is very possible to become a movement that is concerned with environmental sustainability. Likewise, Siringi (2012), Andrew \& Slamet (2013), and Smith (1998) that the formation of awareness and awareness of environmentally friendly products is a consideration for green consumers to behave.

\section{Conclusion}

1Based on the results and discussion, several things that can be concluded related to the development of the green consumer behavior model in North Sulawesi are as follows:

1. Research findings prove that green marketing has a positive relationship and a significant influence on green consumerism with green consumer behavior as a mediating variable.

2. Research findings prove that the theory of planned behavior has a positive relationship and a significant influence on green consumerism with green consumer behavior as a mediating variable

3. Research findings prove that green marketing has a positive relationship and a significant influence on environmental sustainability with green consumer behavior as a mediating variable

4. Research findings prove that the theory of planned behavior has a positive relationship and a significant influence on environmental sustainability with green consumer behavior as a mediating variable.

5. Research findings prove that green consumerism and environmental sustainability are influenced by green consumer behavior.

\section{References}

Agustin, Kumadji, dan Yulianto, 2015. Pengaruh Green Marketing Terhadap Minat Beli Serta Dampaknya Pada Keputusan Pembelian (Survei Pada Konsumen Non-Member Tupperware Di Kota Malang). Jurnal Administrasi Bisnis (JAB), 22(2), 1-10. Retrieved from administrasibisnis.studentjournal.ub.ac.id

Ajzen, I. 1988. "Attitude, Personality, and Behavior". Dorsey, Chicago, I.L.

Ajzen, I. 1991, "The Theory Of Planned Behavior", Organizational Behavior and Human Decision Processes, Vol. 50 No. 2, pp. 179-211.

Andrew \& Slamet, 2013. Pengaruh Environmental Behavior Terhadap Green Purchasing Behavior Pada Anak Muda Generasi C Di Jakarta. Peran Perbankan Syariah Dalam Penguatan Kapasitas UMKM Menuju Kemandirian Ekonomi Nasional, 1993 (April), 10-20

Anika, 2014. A Survey on Green Marketing. International Journal of Engineering Sciences Paradigms and Researches, 15(1), 37-42. Retrieved from www.ijesonline.com

Daniel, Wayne W. and James C. Terrel, 1989, Business Statistics For Management And Economics, Houghton Mifflin Company, Boston

Engel \& Blackwell, 1982. Consumer behavior. Dryden Press. Retrieved from https://books.google.co.id / books/about/Consumer_Behavior.html?id=aHsHN CvBpecC\&redi esc=y

Gardner \& Stern, 2002. Environmental problems and human behavior. Pearson Custom Pub.

Istantia, Kumadi, \& Hidayat, 2016. Pengaruh Green Marketing terhadap citra merek dan keputusan Pembelian (Survei pada Pengguna Produk Ramah Lingkungan Lampu Philips LED di Perum Kepanjen Permai 1, RW 4, Desa Talangagung, Kec.Kepanjen, Malang, Jawa Timur). Jurnal Administrasi Bisnis (JAB), 32(1),174182.

Lee, 2014. Predictors of Sustainable Consumption among Young Educated Consumers in Hong Kong. Journal of International Consumer Marketing, 26(3), 217-238.

M. Laroche et al., 2001. Targeting consumers who are willing to pay more for environmentally friendly products. Journal of Consumer Marketing, 18(6), 503-520.

Morelli, 2011. Environmental Sustainability: A Definition for Environmental Professionals. Journal of 
Environmental Sustainability, 1(1), 1-27. http://doi.org

Nair \& Maram, 2015. Towards Sustainable Consumption: Analyzing Green Consumer Behaviour Towards Sustainable Consumption: Analyzing Green Consumer. In Contemporary Issues and Emerging Trends (pp. 1-13). SDMIMD Mysuru.

Nandini, 2016. Green Marketing A Way To Sustainable Development. Anveshana's International Journal Reserach in Regional Studies, Law, Social Science, Journalism and Management, 1(5), 20-26.

Silvia, H, \& Kusumawati, 2014. Pengaruh Pemasaran Hijau Terhadap Citra Merek Serta Dampaknya Pada Keputusan Pembelian (Survei pada Konsultan Independen di Oriflame Cabang Surabaya ). Jurnal Administrasi Bisnis (JAB), 14(1), 1-9.

Siringi, 2012. Determinants of Green Consumer Behavior of Post graduate Teachers. IOSR Journal of Business Management, 6(3), 19-25. Retrieved from www.iosrjournals.org

Smith, 1998. The Myth of Green marketing: Tending Our Goals at the Edge of Apocalypse, University of Toronto Press

Sumarwan, 2011. Perilaku Konsumen: Teori dan Penerapannya dalam Pemasaran | Publikasi MB-IPB (2nd ed.). Bogor: Ghalia Indonesia 